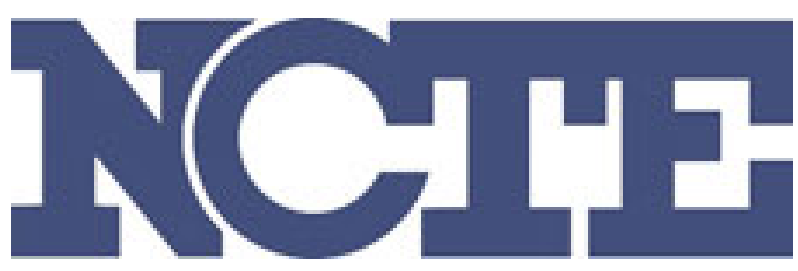

Scripting Screenplays: An Idea for Integrating Writing, Reading, Thinking, and Media Literacy

Author(s): Lawrence Baines and Micah Dial

Source: The English Journal, Vol. 84, No. 2 (Feb., 1995), pp. 86-91

Published by: National Council of Teachers of English

Stable URL: http://www.jstor.org/stable/821058

Accessed: 21/11/2014 17:56

Your use of the JSTOR archive indicates your acceptance of the Terms \& Conditions of Use, available at

http://www.jstor.org/page/info/about/policies/terms.jsp

JSTOR is a not-for-profit service that helps scholars, researchers, and students discover, use, and build upon a wide range of content in a trusted digital archive. We use information technology and tools to increase productivity and facilitate new forms of scholarship. For more information about JSTOR, please contact support@jstor.org. 


\section{Scripting Screenplays: An Idea for Integrating Writing, Reading, Thinking, and Media Literacy}

Lawrence Baines and Micah Dial

very step from savagery to civilization is dependent upon the invention of media which enlarge the range of purely immediate experience and give it deepened as well as wider meaning by connecting it with things which can only be signified or symbolized."

-John Dewey (1966, 232)

If you try to begin a conversation with a student about a recently released young adult novel or a literary classic, chances are that she or he will have precious little to say. If you try to begin a conversation with a student about a recently released film (say, the cinematic version of Michael Crichton's Jurassic Park) or a television show (Beverly Hills 90210, for example), chances are you will become en-

Our students know the movies, and we can use their familiarity in screenwriting activities.

\section{gaged in a lively discussion.}

For better or worse, students are becoming increasingly attuned to the moving image and less patient with mere words on a page. More than sixty years ago, Samuel Rosenkranz wrote that teachers "refuse to recognize the fact that they [students] are going to the picture shows, and that we must adapt our literature and composition courses in such a manner that adequate recognition is given to the fact that there are some genuine needs to be met" (Rosenkranz 1931, 824).

Today, VCRs exist in over seventy-five percent of American homes, television sets stay turned on for over seven hours a day, cable television operators offer hundreds of viewing alternatives, and students spend hours playing video games, so getting students to spend time reading or writing is more challenging than ever. For further proof of the appeal of the moving image, compare the number of teenagers in the crowds in the video store waiting to check out the new releases with the number of teenagers loitering around the "new releases" section of books at the local library. In re- sponse to the electronic media's usurpation of student attention, many state and federal officals have urgently delivered edicts to parents that they "turn off their televisions" and instead encourage their children to read. Despite such advice, the networks, Hollywood, and cable television companies have managed to eke out enough profit to stay in business: Undeniably, most students spend more time with nonprint media than with books.

TEN REASONS TO USE

SCREENWRITING IN ENGLISH CLASS

Screenwriting is one effective way to use students' familiarity with the electronic media to foster reading, writing, and media literacy. Screenwriting in English class has the following positive attributes:

1. Screenwriting motivates students to write. Because most students have spent more time in front of their television sets and in movie theaters than at home reading literary classics, they are interested in "writing a movie."

2. Screenwriting involves a full-blown writing process and more. Students brainstorm, research, write character biographies, visually construct scenes, critique the writing of peers, and must be able to effectively write dialogue as well as description.

3. Screenwriting requires both individual and group work. While much of the initial writing in the unit requires that students work individually, when it comes time to shoot the video, students must negotiate their individual roles within their groups, discuss, and select the screenplay to be shot, and decide on how to go about shooting it.

4. Screenwriting forces students to think in terms of camera angles, music, words, and images. Screenwriting surreptitiously teaches students how the components of the electronic media work to communicate their messages. Presto! Media literacy.

5. Screenwriting invokes all of the seven intelligences hypothesized by Howard 
Gardner in Frames of Mind (1983). Students write dialogue and description (linguistic); are compelled to create, visualize, write, and negotiate meaning as individuals (intrapersonal) and with other students (interpersonal); calculate time intervals and match time expectations against the scriptwriting paradigm (mathematical); furnish music and sound effects to accompany the action (musical); map out scenes using existing locations or building suitable sets (spatial and kinesthetic); and put everything together in a filmed or live presentation (a synthesis of diverse talents).

6. Screenwriting involves hands-on, active learning for students in a real-life situation. Students find it virtually impossible to hide or slough off during this activity.

7. Screenwriting has been the most lucrative writing profession in the twentieth century. While many writers struggle at making a living churning out novels and poetry, screenwriters are relatively wellpaid and healthy. William Faulkner, James T. Farrell, Aldous Huxley, F. Scott Fitzgerald, Theodore Dreiser, Ring Lardner, John Steinbeck, Raymond Chandler, Richard Wright, Nathaniel West, Gore Vidal, Beth Henley, Arthur Miller, Edward Albee, Harold Pinter, Tennessee Williams, Billy Wilder, Elia Kazan, Neil Simon, David Cronenburg, Stephen King, William Goldman, James Michener, and others have written screenplays at one time or another in their careers. Writers in Hollywood, 1915-1951 (Hamilton 1990) recounts how a bevy of American literary stalwarts were lured to Hollywood by the promise of big dollars. In 1939, F. Scott Fitzgerald was making $\$ 1,500$ a week writing in Hollywood, while his book royalties during 1939 brought in a grand total of $\$ 33.00$.

8. Screenwriting may lead to scripts which may be filmed by students or offered to the drama department for the production of an original play or video. If the screenplays get filmed, the videos could be shown at open house, after Channel One viewing (if the school subscribes), or during "dead" times during the school year (such as on exam days or the last day of the grading period). Other inter-disciplinary connections are certainly possible - math and industrial arts classes could help design and build sets, art classes could paint and shape them, science classes could help develop special effects, history classes could help supply pertinent background information about certain periods of time.

\section{Screenwriting is writing with portfolio} possibilities. Some literary giants did not transfer their brilliance to the screen because they could not adjust their writing styles for film. Writing well for the screen is challenging, intense work, and it is certainly different than writing pure prose. While providing students with another avenue of expression with which to experiment, a screenplay and a video would also add contemporary touches to any student portfolio.

10. Screenwriting is fun. Students often groan when they receive writing assignment after writing assignment, but complaints usually recede (at least momentarily) during a screenwriting unit. Students seem to enjoy a feeling of accomplishment when they see works they have created in print and on film.

\section{SOURCES AND ACTIVITIES}

I adapted materials for the screenplay unit from four major sources-two of Syd Field's books, The Screenwriter's Workbook (1984) and Screenplay: The Foundations of Screenwriting (1981); John Gardner's The Art of Fiction (1984); and the last hundred pages of William Goldman's Adventures in the Screen Trade (1984) in which Goldman transposes one of his shorter short stories into an actual screenplay. I have used the screenwriting unit concurrently with other classroom activities or as a unit in itself.

Listed below are a chronology of activities and writing assignments that can help students to complete their own screenplays.

\section{Activity One: Brainstorming for Ideas}

Required writing:

Favorite films list

Elements of film identification

Idea for a script in one sentence

To begin, students do three short, shotgun writing assignments.

First, they list their all-time favorite films (at least ten). Next, they identify common elements on their favorite films list. Do they enjoy suspense, action, westerns, detective stories, romance, adventure, or documentaries?

The third assignment, composed after the first two assignments have been completed, is a description of two or three films that they would like to see made. One student, Jayne, wrote, "I'd like to see a film of a romance between a black man and a black woman, without any explicit sex or psycho 
killers in it. Real love." From these three pieces-the favorite films list, the description of the elements that they enjoy seeing in films, and the idea generation for their scripts-students jot down a general idea for a film in one sentence on a sheet of paper. This one-sentence summary should answer the question, "What is the film about?"

\section{Activity Two: Structuring the Idea Required writing:}

Break-down of the script idea into setting, conflict, and resolution with 3-4 sentences about each section.

Whereas novelists have the freedom to "let the story take over," screenwriters must abide by a set pattern of development. According to Field, "A screenplay follows a certain, lean, tight, narrative line of action, a line of development... [which] always moves forward, with direction toward the resolution" $(1984,12)$. Basically, the screenplay contains three parts: the establishment of the setting, the introduction of the conflict, and the resolution.

At the beginning of the movie, Raiders of the Lost Ark, for example, director Stephen Spielberg establishes the setting by showing the discovery somewhere in the Middle East of an ancient artifact thought to possess mystical powers. The conflict comes when the lead character, Indiana Jones, discovers that the Nazis, who are seeking the same artifact, try to keep him and his companions from their search. The resolution involves Jones' escape from the Nazis and the Nazis' eventual comeuppance.

Usually, about half of a screenplay is devoted to the main action, or the conflict of a story, with approximately a fourth used to establish the setting and another fourth to provide a resolution. Students write several sentences (most students do it in three or four sentences) for each section in order to flesh out their ideas for the three parts of the story.

For example, Keli described the conflict in her story this way:

Diane can't stand her mother's new boyfriend, Tyrone. Something about him gives Diane the creeps. The mom acts totally different, kind of like one of Diane's more immature friends, when Tyrone is around. Tyrone never talks about his work, says he is "an independent businessman." One night when she goes out with a wild friend (Shantell), Diane sneaks into a nightclub. In the nightclub, she spots Tyrone at a table with a woman.

Although Diane comes up and says "hello," Tyrone acts like he doesn't recognize her.

\section{Activity Three: Character Biographies Required writing:}

List of all main characters with brief descriptions about each

In-depth description of at least one main character

Students list adjectives or write a paragraph describing the physical and emotional dimensions of all major characters. For example, Juan described one of his characters this way:

Garth is like Clint Eastwood probably was at 16 , doesn't say much, isn't that good-looking, but still has all these high school girls, and even some college girls crazy for his bod. The guys don't really like him because they know that if they pick on him, he's going to hit back. And he's going to hit back hard.

Next, students zero in on one (or more) main character(s) who will be the focus of the screenplay and write in more detail about them. These biographies might include a physical description (height, weight, usual type of dress), information concerning the way the character sits, walks, and speaks; the place in which he/she lives, friends, job, hobbies, mannerisms, political beliefs, habits, and other pertinent details. The phrase that many writing teachers repeat often, "Show, don't tell," is equally critical in getting students to create believable, interesting characters for film.

For his in-depth character biography, Will wrote:

Joey is an office worker. He wears a tie and sportscoat to work even though he hates ties. He's neat and tidy around others, but when he works alone, his personal appearance leaves much to be desired. ... Some days, he's the most intelligent man on the planet. He can work any mathematical equation, solve any problem with the system, and complete tasks with inhuman speed and efficiency. Then there are those days when he's totally snapless. Like the time he left the printer on and went for a coffee break, 
only to come back to 2,463 copies of

"Your Printer and You."

\section{Activity Four: Describing Plot and Setting by Scene \\ Required writing:}

Scenes/locations written out on $3^{\prime \prime} \times 5^{\prime \prime}$

index cards.

Once students have sketched out a basic storyline and know the main characters in their stories, they are ready to begin describing the setting and the plot. I show a video montage of the first minute (after the credits) from the opening of the films The Chocolate War, Sounder, To Kill a Mockingbird, The Outsiders, Ship of Fools, I am the Cheese, The Color Purple, Hamlet, and The Rocking Horse Winner. After seeing the video, students discuss the words and the images evident in the first minute of each film that helped establish its setting. Students write a short summary of their opening scene on an index card.

To help show how authors change scenes to keep the action lively, I ask the class to analyze how Shakespeare shifted locations in the first few pages of Macbeth. Specifically, the first scene of Macbeth involves three witches reciting a riddle in a deserted heath; the second is at King Duncan's camp outside of Forres. For the third, it's back to the heath and the witches; the fourth takes place in a room inside Duncan's castle in Forres, and the fifth is at Inverness, Macbeth's castle.

Students get out all of their previous writings (character sketches, plot summary, description of the setting on an index card) and spread them out so they can see all of them at once. Then they decide a possible series of events that might happen to their main character(s). On $3^{\prime \prime} \times 5^{\prime \prime}$ index cards, students write no more than one or two sentences about the locations that the main character might visit.

Matt, for example, wanted to write a story about a football player, a senior in high school, who gets caught cheating on his final exam in English, thus endangering his chances at graduation and an athletic scholarship. The first scene showed the senior cruising the hallways, talking with his friends between classes. In the second scene, the senior was at the football practice field where the team worked out after school. The third scene moved to the coach's office, where a coach tells him about a possible visit by a recruiter from a big-name college. The fourth scene took place at home, where the senior struggles to understand his school notes, then constructs a cheat sheet on a scrap of paper. In this manner, Matt visualized the basic locales for his story.

\section{Activity Five: Backtrack the Main Character Twenty-four Hours Before the Story Takes Place \\ Required writing:}

Short piece of fiction that puts the main character into action for a day.

When I first started asking students to write scripts, I discovered that many students attempted to begin their stories from the very beginning rather than in medias res. Backtracking the main character for twentyfour hours before the story takes place familiarizes the student with the thought processes of the main character(s) at the moment that the screenplay opens. Some students enjoy writing the backtrack so much that they want to begin their screenplays a day earlier. That is fine, but students still should be encouraged to write another 24hour backtrack from whence the story opens.

\section{Activity Six: Getting Students Familiar with the Format of the Screenplay Required writing:}

A brief screen adaptation of a short story done in groups.

There is nothing arduous about the format for screenplays. The name of the character who is speaking is written in all-capital letters in the middle of a page (about four inches from the left edge of the paper) over the dialogue, which is single-spaced and indented about 10 spaces from the left margin. Descriptions of how characters deliver lines may be written in parenthesis with the dialogue. Directions about where and when the action takes place are written in all capital letters flush against the left margin. Two lines should be skipped in between lines of dialogue and stage directions.

To get students familiar with the format of a screenplay, I assign a group project where they transpose short stories with much dialogue or action (such as Hemingway's "The Indian Camp" or a scene from Ernest Gaines' "The Sky is Gray") into screenplays. I keep copies of screenplays 


During the
screenwriting
unit, students
want to write
and film the
best video
ever made.

from several popular films in class as examples.

\section{Activity Seven: Writing the Screenplay Required writing: \\ Initial draft of a screenplay.}

Field (1984) suggests that the main character, the dramatic premise, and the circumstances surrounding the action be introduced within the first few pages of the script. In other words, all the work assigned in the previous activities-the character sketch, the screenplay paradigm (in which students decided on conflict, setting, and resolution), the 24-hour backtrack, the ten to twenty notecards, the sample screenplay adaptation of a short story-should have an impact on the construction of the first few pages. In most films, the opening ten minutes or so involves following the main character around so that the audience can get a "feel" for the story.

Students use their index cards as a base structure around which to build the action of the story and often revise their cards through the first day of filming. Length of screenplays vary with each student's level of interest, attention span, and patience. Generally, one page of a script is equivalent to one minute of screen time, so a script of twenty-five pages would last approximately twenty-five minutes.

\section{Activity Eight: Peer Editing, Shooting the Video, Showing Off the Results.

During peer editing, students get into groups of four to six and share their screenplays. Every student reads the scripts of all members of the group with the intent of deciding which screenplay would likely make the best film. Each student responds to all screenplays, noting out good points, scenes that they did not like or understand, and parts of the story that might be difficult to capture on film. The group votes on which screenplay to shoot and who will act as the stars, the cinematographer, the set designer, and the director.

Two class periods during the unit are "on the set" days when I check out video cameras from the library and allow students to videotape in the classroom or on school grounds. Most groups want to film after school, so I use the video cameras furnished by parents of group members or check video cameras out with the library after school.

After all videos have been shot and the videotapes and scripts turned in, students respond individually on a group assessment form concerning each member's contribution (including their own) to the group. Inevitably, it will take some groups longer to produce a finished video than others. I always give non-negotiable deadlines first, then negotiate once I see students feverishly working to finish their projects.

Few activities match the excitement of the premiere of a student-produced, student-scripted, student-acted video. However, to keep the level of excitement in scripts and videos high, premieres are usually limited to two to four (depending on length) per week.

\section{THE POWER OF SCREENWRITING}

Because many products of the electronic media aspire to be nothing more than profitable pap and succeed beautifully at it, educators have often viewed television, video, and film with a certain degree of contempt. True, the language of film and television is not as sophisticated as that of literature (Baines 1993). But, Ong (1967, 1982) has pointed out that film and television still rely primarily on words to communicate their messages. Television shows and movies are derived from written scripts which are constructed and revised well before any actual production begins.

Screenwriting is difficult, challenging work involving writing, rewriting, and more rewriting. It is a way to get previously lackadaisical students to produce stacks of written work about characters, plot, setting, dialogue, conflict, and description. In addition, students are compelled to think critically about writing, images, and sounds; they experience first-hand how nonprint media can be manipulated for specific purposes; they collaborate actively with their peers and use a variety of skills and intelligences. Perhaps most importantly, during the screenwriting unit, students want to write and film the best video ever made. And when students want to do well, teaching is a blast. 


\section{Works Cited}

Baines, Lawrence. 1993. Aspects of Language in Literature and Film. Unpublished dissertation, Ann Arbor, MI: University of Michigan.

Dewey, John. 1966. [c. 1916] Democracy and Education. New York: Free Press.

Field, Syd. 1981. Screenplay: The Foundations of Screenwriting. New York: Dell.

- 1984. The Screenwriter's Workbook. New York: Dell.

Gardner, John. 1984. The Art of Fiction. New York: Alfred Knopf.

Gardner, Howard. 1983. Frames of Mind. New York: Basic Books.

Goldman, William. 1984. Adventures in the Screen Trade. New York: Dell.

Hamilton, Ian. 1990. Writers in Hollywood 19151941. New York: Harper and Row.

Ong, Walter. 1967. The Presence of the Word. New Haven: Yale University Press.

. 1982. Orality and Literacy. New Haven: Yale University Press.

Rosenkranz, Samuel. 1931. "English at the Cinema." English Journal 20:10 (Dec.): 824.

\section{Screenplay Resources}

Eastman, Charles. 1969. Little Fauss and Big Halsey. New York: Farrar, Straus, and Giroux.

Faragoh, Francis. 1981. Little Caesar. Madison, WI: University of Wisconsin Press.

Fitzgerald, F. Scott. 1978. [c. 1938] Three Comrades. Carbondale, IL: Southern Illinois Press.

Goodrich, Francis, Albert Hackett, Frank Capra, and Jo Swerling. 1986. It's a Wonderful Life: A Screenplay. New York: St. Martin's.

Sayre, Joel, and William Faulkner. 1981. [c. 1936] The Road to Glory. Carbondale, IL: Southern Illinois University Press.

Stone, Oliver, and Richard Boyle. 1987. Oliver Stone's Platoon and Salvador. New York: Vintage Books.

Lawrence Baines teaches at Florida State University in Tallahassee. Micah Dial is a research associate for education and training programs with EDAS in Houston.

\section{GREENWOODPRESS presents a new series}

\section{The Greenwood Press “Literature in Context” Series}

\begin{abstract}
In response to requests from secondLary school librarians for resources to support interdisciplinary approaches to literature, Greenwood proudly launches "Literature in Context," a unique series of sourcebooks designed to serve as a resource for students studying literature in the historical, social, and cultural context of its time. Each sourcebook is a rich collection of historical documents, collateral readings, and commentary designed to work with the literature to bring past and present into sharper focus and to provide materials for the student to make connections between literature and history.
\end{abstract}

Forthcoming in the series are sourcebooks to:

- Huckleberry Finn

- Anne Frank's Diary of a Young Girl

- Hamlet, and others.

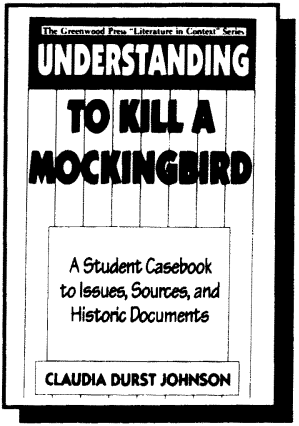

\section{Understanding}

To Kill a Mockingbird

A Student Casebook to Issues,

Sources, and Historic Documents

By Claudia Durst Johnson

Greenwood Press. 1994. 248 pages.

$0-313-29193-4 . \$ 35.00$

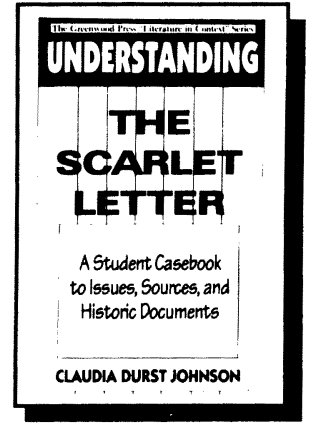

Understanding

The Scarlet Letter

A Student Casebook to Issues,

Sources, and Historic Documents By Claudia Durst Johnson

Greenwood Press. 1995. 272 pages. $0-313-29328-7 . \$ 35.00$

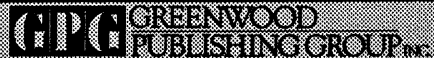

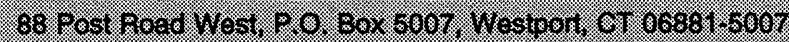

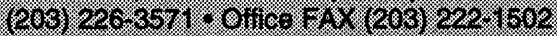

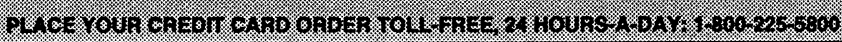

